\title{
HAKEKAT NILAI PERSATUAN DALAM KONTEKS INDONESIA (Sebuah Tinjauan Kontekstual Positif Sila Ketiga Pancasila)
}

\author{
Hanafi \\ Program Studi Pendidikan Pancasila dan Kewarganegaraan, Universitas Negeri Malang \\ J1. Semarang No.5 Malang \\ email: hanafiress@gmail.com
}

\begin{abstract}
This article described the existence of Pancasila as an ideology which has several important functions to regulate the life of the nation and state.Especially through the principles of Indonesian unity. The method used is library research or library research. The results showed that Pancasila was an unifying national ideology that was right for the Indonesian nation, as a new instrument should be held in order to reactualize the values of Pancasila in Indonesian society. A great nation is a nation that is able to withstand its ideology by maintaining a unity in it as a whole.
\end{abstract}

Keywords: essence, value, unity, Pancasila, Indonesia

\begin{abstract}
Abstrak: Artikel ini mendeskripsikan keberadaan Pancasila sebagai ideologi yang di dalamnya memuat beberapa fungsi penting untuk mengatur kehidupan berbangsa dan bernegara. Terutama melalui sila persatuan Indonesia. Metode yang digunakan adalah kajian kepustakaan atau library research. Hasil dari kajian menunjukan bahwa Pancasila adalah sebuah ideologi pemersatu bangsa yang sudah tepat bagi bangsa Indonesia, selayaknya diadakan instrumen baru dalam rangka mereaktualisasi nilai-nilai Pancasila dalam kehidupan bermasyarakat Indonesia. Bangsa yang yang besar adalah sebuah bangsa yang mampu bertahan dengan ideologinya dengan cara menjaga persatuan di dalamnya secara utuh.
\end{abstract}

Kata kunci: hakekat, nilai, persatuan, Pancasila, Indonesia

Minimnya pengetahuan masyarakat terkait apa itu yang dimaksud dengan Pancasila menjadi tantangan baru dalam alam reformasi. Setelah runtuhnya rezim orde baru yang terkenal dengan P-4 nya (Pedoman Penghayatan dan Pengamalan Pancasila) kini konsepsi tuntunan bahan ajar untuk masyarakat semacam itu tidak muncul lagi dalam permukaan bumi Indonesia. Pancasila adalah sebuah ideologi pemersatu bangsa sudah selayaknya diadakan instrumen baru dalam rangka reaktualisasi nilai-nilai Pancasila dalam kehidupan bermasyarakat Indonesia.

Melalui tulisan ini diharapkan manusia Indonesia tidak hanya sekedar berhenti dalam tataran mengetahui terkait apa itu Pancasila, namun diharapkan agar bangsa ini mampu memahami apa itu arti nilai-nilai luhur Pancasila itu, bahkan sampai masuk dalam tataran hakikat Pancasila. Bangsa yang yang besar adalah sebuah bangsa yang mampu bertahan dengan ideologinya dengan cara menjaga persatuan di dalamnya secara utuh. Nilai persatuan adalah sebuah obat yang paling mujarab dalam rangka mewujudkan cita-cita kebangsaan yang berpersatuan. Oleh karena itu, bangsa Indonesia harus tetap menjaga persatuan yang ada dalam negara ini. Walaupun banyak perbedaan tetapi tetaplah satu kesatuan dalam kerangka Negara Kesatuan Republik Indonesia. Selain itu, dirasa perlu juga untuk memulihkan kesadaran untuk memahami makna substansial (hakekat) khususnya dari sila ketiga "Persatuan Indonesia" dalam pribadi masyarakat Indonesia agar masyarakat Indonesia menyadari betapa pentingnya persatuan dalam suatu kehidupan berbangsa dan bernegara.

\section{HASIL DAN PEMBAHASAN}

\section{Hakekat Nilai Persatuan Sebagai Konsep Pengetahuan Bangsa Indonesia}

Manusia Indonesia kontemporer abad 21 dirasakan sudah tidak menjadi penikmat akan 
kesakralan nilai-nilai luhur Pancasila. Minimnya pengetahuan mereka ditunjang lagi dengan minimnya kesadaran moralitas pemangku jabatan pemerintahan Indonesia untuk membudayakan kembali nilai-nilai luhur tersebut menjadi causa baru dalam babak Indonesia yang kini hanya terlihat menempatkan ideologi Pancasila sebagai sebuah nama tanpa makna. Pembaca yang budiman sebelum jauh kita memahami Nilai Pancasila khususnya sila ketiga dalam tahapan filosofis, alangkah baiknya kita mengetahui terlebih dahulu apa itu yang dimaksud dengan Sila Persatuan Indonesia.

Sila ketiga Pancasila yaitu "Persatuan Indonesia", yang terdiri atas 2 (dua) kata yaitu Persatuan (S) dan Indonesia (ket). Kata persatuan terdiri atas akar kata "satu" + imbuhan per-/-an kemudian menjadi "persatuan". Secara morfologi kata persatuan berarti suatu hasil dari perbuatan (nomina). Sedangkan dari sudut dinamikanya pengertian persatuan yaitu suatu proses yang dinamis "Indonesia" adalah merupakan suatu kuantitas yaitu persatuan untuk wilayah, bangsa dan negara.

Sila ketiga dari falsafah pancasila ini semula dalam konsepsi Bung Karno yang dinamakan Kebangsaan Indonesia atau nasionalisme. Sila ini merupakan suatu formulasi yang mencermikan faham hidup yang dikenal dengan faham individualisme, yaitu faham yang manakala berdiri sendiri tanpa didampingi oleh faham lainnya akan menjadi dasar titik tolak lahirnya faham liberlisme. Sila ini semula dimaksudkan untuk menjadi pengimbang terhadap" internasionalisme tidak dapat hidup subur jika tidak berakar dalam buminya yaitu nasionalisme".

Menurut Notonegoro (dalam Kaelan, 2009 : 187) Prinsip-prinsip Nasionalisme Indonesia (Persatuan Indonesia) tersusun dalam kesatuan majemuk tunggal yaitu:

1. Kesatuan sejarah, yaitu bangsa Indonesia yang tumbuh dan berkembang dalam suatu proses sejarah, sejak zaman prasejarah, Sriwijaya, Majapahit, Sumpah Pemuda 28 Oktober 1928 dan sampai Proklamasi 1945 dan kemudian membentuk negara Republik Indonesia.

2. Kesatuan nasib, yaitu berada dalam satu proses sejarah yang sama dan mengalami nasib yang sama yaitu dalam penderitaan penjajahan dan kebahagiaan bersama.
3. Kesatuan kebudayaan, yaitu keanekaragaman kebudayaan tumbuh menjadi suatu bentuk kebudayaan nasional.

4. Kesatuan wilayah, yaitu keberadaan bangsa Indonesia tidak bisa dipisahkan dengan wilayah tumpah darah Indonesia.

5. Kesatuan asas kerokhanian, yaitu adanya ide, cita-cita dan nilai-nilai kerokhanian yang secara keseluruhan tersimpul dalam Pancasila.

Dalam pembukaan UUD NRI Tahun 1945 alinea II disebutkan suatu negara yang merdeka, berdaulat, adil dan makmur. Yang dimaksud dengan negara Indonesia yang bersatu yaitu suatu negara persatuan. Maka kesatuan dan persatuan bangsa adalah merupakan suatu sendi negara. Negara Indonesia bukanlah negara yang terbagibagi dalam kalimat "Negara melindungi segenap bangsa Indonesia" dan "seluruh tumpah darah Indonesia". Tujuan yang demikian mengandung arti bahwa negara Indonesia, bangsa Indonesia dan wilayah tanah air Indonesia adalah merupakan suatu kesatuan.

Pengertian "Persatuan Indonesia" juga dijelaskan dalam penjelasan resmi Pembukaan UUD NRI Tahun 1945 yang termuat dalam Berita Republik Indonesia Tahun ke II, No.7, bahwa mendirikan negara Indonesia, digunakan aliran pengertian "Negara Persatuan" yaitu negara mengatasi segala paham golongan dan paham perseorangan, jadi bukan negara berdasar individualisme, dan juga bukan negara yang mengutamakan klass staat (negara klasa) yang mengutamakan satu golongan. Maka negara Indonesia adalah negara yang berdasarkan asas kekeluargaan, tolong menolong, menolong atau dengan dasar keadilan sosial. Maka dapat dipahami bahwa tujuan mendirikan negara Indonesia antara lain adalah mengutamakan seluruh bangsa Indonesia.

Penjelasan lain, menurut Kaelan $(2009 ; 117)$ dideskripsikan bahwa Sila Persatuan Indonesia mengandung pengertian sebagaimana berikut:

1. Negara Indonesia yang bersatu adalah hasil perjuangan gerakan kemerdekaan Indonesia yang telah sampai kepada saat yang berbahagia dan selamat sentausa mengantarkan rakyat Indonesia ke depan pintu gerbang kemerdekaan Indonesia, serta terlaksananya cita-cita kemerdekaan (Pembukaan UUD 1945 alinea II)

2. Negara melindungi segenap bangsa dan seluruh tumpah darah Indonesia (Pokok pikiran I) 
3. Negara Indonesia adalah Negara kesatuan yang berbentuk Republik (Pasal 1 UUD 1945)

4. Negara melindungi segenap bangsa dan seluruh tumpah darah Indonesia dengan berdasarkan atas persatuan Indonesia (Pembukaan UUD 1945 alinea IV)

5. Warga Negara ialah orang-orang Indonesia asli dan orang-orang asing yang disahkan dengan undang-undang sebagai warga Negara Indonesia (Pasal 26 ayat (1) UUD 1945)

6. Bahasa negara adalah bahasa persatuan adalah bahasa Indonesia (Pasal 36 UUD 1945)

7. Lambang persatuan dan kesatuan bangsa dan negara Indonesia adalah Bhinneka Tunggal Ika

8. Wawasan dalam mencapai tujuan pembangunan Negara wawasan nusantara mencakup:

a. Perwujudan kepulauan nusantara sebagai satu kesatuan politik

b. Perwujudan kepulauan nusantara sebagai satu kesatuan budaya

c. Perwujudan kepulauan nusantara sebagai satu kesatuan ekonomi

d. Perwujudan kepulauan nusantara sebagai satu pertahanan dan keamanan

\section{Hakekat Nilai Persatuan Sebagai Konsep Pemahaman Bangsa Indonesia}

Makna substansial atau hakekat juga dapat disebut sebagai makna atau pemahaman filosofis dari Pancasila itu sendiri terutama sila Persatuan Indonesia. Secara filosofis Pancasila merupakan suatu kesatuan yang bertingkat (hierarkis) dan berbentuk piramidal. Nilai yang terkandung dalam sila Persatuan Indonesia tidak dapat dipisahkan dengan keempat sila lainnya karena seluruh sila merupakan suatu kesatuan yang bersifat sistematis. Sila Persatuan Indonesia didasari dan dijiwai oleh sila Ketuhanan Yang Maha Esa dan Kemanusiaan yang Adil dan Beradab serta mendasari dan menjiwai sila Kerakyatan yang Dipimpin oleh Hikmat Kebijaksanaan dalam Permusyawaratan/Perwakilan dan Keadilan Sosial bagi Seluruh Rakyat Indonesia.

Sila ketiga ini mempunyai maksud mengutamakan persatuan atau kerukunan bagi seluruh rakyat Indonesia yang mempunyai perbedaan agama, suku, bahasa, dan budaya, sehingga kemudian dapat disatukan melalui sila ini. tujuannya jelas yaitu meski berbeda-beda tetapi tetap satu atau dapat disebut dengan
Bhinneka Tunggal Ika.Persatuan Indonesia mengutamakan kepentingan dan keselamatan negara dari pada kepentingan golongan pribadi atau kelompok seperti partai, ras, agama dan golongan. Hal yang dimaksudkan dari hal tersebut adalah sangat mencintai tanah air Indonesia dan bangga mengharumkan nama Indonesia. Sila ini menanamkan sifat persatuan untuk menciptakan kerukunan kepada rakyat Indonesia.

Sila ini juga dimaksudkan untuk memelihara ketertiban yang berdasarkan kemerdekaan, perdamaian abadi, dan keadilan sosial bagi seluruh rakyat Indonesia. Persatuan Indonesia adalah satu untuk Indonesia walaupun keadaan di masyarakat sangat penuh perbedaan tetapi harus menjadi satu darah Indonesia dan rela mengorbankan kepentingan golongan demi negara Indonesia, meskipun diketahui bahwa dalam masyarakat Indonesia sangat kental dengan berbagai budaya yang berbeda, namun tetap harus rukun menjaga kedamaian Bhineka Tunggal Ika itu sendiri.

Sila Persatuan Indonesia, di dalamnya terkandung nilai bahwa negara adalah sebagai penjelmaan sifat kodrat manusia monodualis yaitu sebagai makhluk individu dan makhluk sosial. Negara merupakan suatu persekutuan hidup bersama diantara elemen-elemen yang membentuk negara yang berupa suku, ras, kelompok, golongan, maupun kelompok agama. Oleh karena itu perbedaan adalah merupakan bawaan kodrat manusia dan juga merupakan ciri khas elemen-elemen yang membentuk negara. Konsekuensinya, negara adalah beraneka ragam tetapi satu, mengikatkan diri dalam suatu persatuan yang dilukiskan dalam suatu seloka Bhinneka Tunggal Ika. Perbedaan bukannya untuk diruncingkan menjadi konflik dan permusuhan melainkan diarahkan pada suatu sintesa yang saling menguntungkan yaitu persatuan dalam kehidupan bersama untuk mewujudkan tujuan bersama.

Pada hakekatnya dalam diri setiap manusia terdapat dua dorongan nafsu yang paling utama, yaitu dorongan ke-aku-an tau ichhaftigkeit, dorongan ke-kita-an atau dorongan Wirhaftigkeit. Kedua dorongan tersebut manakala salah satunya terlalu dominan akan mengakibatkan munculnya penyimpangan psikologi yang akan menganggu stabilitas kepribadiannya. Bila seseorang yang terlalu didominasi oleh Ichhaftingkeit atau didorong untuk semata-mata mengabdi pada diri pribadinya sendiri akan melahirkan sikap 'ego oriented' segala sesuatu diukur dari kepentingan 
dirinya \& segala sesuatu diabdikan untuk dirinya sendiri, walaupun itu merugikan pihak lain. Sebaliknya manusia yang terlalu dikuasai oleh dorongan ke-kita-an akan melahirkan watak yang terlalu berlebih-lebihan pengorbanannya untuk kepentingan orang lain, sementara kepentingan pribadinya sendiri terabaikan.

Sikap seperti di atas adalah sikap altruistik, yaitu sikap yang menyebabkan dirinya lebur dan luluh ditengah lautan manusia tanpa pribadi. Kebangaan terhadap golongan atau kelompoknya ini bagi suatu bangsa bila terlalu berlebihan akan terlihat dalam bentuk rasa nasionalisme yang tidak sehat, yang lazim dikenal dengan istilah Chauvinistik. Sebaliknya kalau suatu bangsa telah kehilangan rasa bangga akan dirinya sebagai suatu bangsa, telah kehilangan national pride dan national dignity, maka keadaan seperti ini akan mengakibatkan timbulnya penyimpangan rasa kebangsaan yang lazim disebut dengan kosmopolitanistik, yaitu suatu sikap yang melihat tidak ada artinya merasa bangga sebagai suatu bangsa.

Akhirnya setelah mempelajari konsep makna substansial (hakikat) dari Sila Persatuan Indonesia, maka nilai yang terkandung dalam sila persatuan Indonesia ini pun dengan demikian sangat didasari dan dijiwai oleh sila Ketuhanan Yang Maha Esa dan sila Kemanusiaan yang Adil dan Beradab. Hal tersebut dikarenakan bahwa nasionalisme Indonesia adalah nasionalisme religious yaitu nasionalisme yang bermoral Ketuhanan Yang Maha Esa. Nasionalisme yang humanitik yang menjunjung tinggi harkat dan martabat manusia sebagai makhluk Tuhan. Oleh karena itu nilai-nilai nasionalisme ini harus tercermin dalam segala aspek penyelenggaraan negara termasuk dalam era globalisasi dewasa ini. Proses demokrasi tanpa mendasarkan pada moral ketuhanan, kemanusiaan, dan memegang teguh persatuan dan kesatuan maka bukan tidak mungkin akan membawa kehancuran bagi bangsa Indonesia seperti halnya telah terbukti pada bangsa lain misalnya negara-negara Balkan atau negaranegara di Afrika dan lain sebagainya.

\section{Hakekat Nilai Persatuan Sebagai Konsep Ketrampilan Bangsa Indonesia}

Pancasila tidak hanya terbatas pada kemampuan untuk melafalkan dan menghafalkan akan setiap bunyi silanya. Pemahaman lain tekait pancasila wajib dijadikan sebagai cara baru untuk pemikiran generasi bangsa yang baru pula. Mengapa saat ini generasi bangsa kurang memahami apa itu makna pancasila? dikarenakan mereka hanya sebatas mengetahui tentang apa itu Pancasila (knowing Pancasila), bukan mengalaminya (doingPancasila). Pada bahasan ini hakikat Pancasila sebagai sebuah konsep ketrampilan artinya bahwa Pancasila harus dijadikan sebagai cara untuk bertindak dalam rangka upaya menyelesaikan persoalan kehidupan bermasyarakat, berbangsa dan bernegara. Sebagai bangsa yang memiliki sejarah kekayaan akan konsep-konsep pemikiran kebaijakan sudah selayaknya kembali kepada fitrah jati diri kebangsaan yang Indonesiawi. Bangsa yang bersar ini tidak selayaknya menjadi bangsa yang lama-kelamaan menuju pada upaya untuk saling memusuhi, saling membedakan, saling berseteru bukan untuk bersatu. Apakah bangsa Indonesia perlu untuk dijajah lagi agar menjadi bersatu? Mungkin ini bukan jawaban yang rasional, akan lebih baiknya jika kita kembali kepada penguatan terkait bahasan ini yaitu kita harus menjadikan konsep nilai persatuan sebagai ketrampilan dalam menyelesaikan persoalan bangsa ini.

Sila Persatuan Indonesia merujuk pada persatuan yang utuh dan tidak terpecah belah atau bersatunya bermacam-macam perbedaan suku, agama, antar golongan dan lain-lain yang berada di wilayah Indonesia. Persatuan ini terjadi karena didorong keinginan untuk mencapai kehidupan kebangsaan yang bebas dalam wadah negara yang merdeka dan berdaulat, memajukan kesejahteraan umum, dan mencerdaskan kehidupan bangsa, serta mewujudkan perdamaian abadi. Sila Persatuan Indonesia merupakan kristalisasi sejarah bangsa Indonesia yang pernah dibuktikannya pada masa penjajahan setelah perjuangan kedaerahan dirasa tidak berhasil. Upaya menggalang persatuan yang dipelopori oleh Bung Tomo di Surabaya, Supriadi di Blitar menjadi bukti dalam pemulaian gerakan persatuan Indonesia awal perjuangan Indonesia abad 19. Ini artinya beliau telah menempatkan nilai persatuan sebagai ketrampilan dalam upaya untuk mengusir penjajah dari bumi Indonesia.

Rasional untuk penguatan kembali nilai persatuan dalam konteks Inodnesia sebagai sebuah konsep ketrampilan mengapa pada saat ini dirasakan cukup sulit jika dibansingkan dengan perjuangan yang sangat jauh berat tingkatannya 
dengan masa perjuangan masa peperangan saat itu. Padahal saat ini kita telah merdeka bebas dari penjajahan fisik. Bukannya hal ini justru sangat mempermudah kita untuk senantiasa belajar dan mengamalkan nilai tersebut. Apa sulitnya kita hanya untuk bersatu, mungkin jawabannya hanya satu yaitu kita terkalu mengagung-agungkan akan nafsu diri kita atau kelompok kita sendiri. Sebagaimana yang disampaikan Bung Karno bahwa makna kebangsaan (nilai persatuan) harus dimengerti bahwa negara Indonesai ini didirikan buka untuk kepenyingan perseorangan atau golongan, baik golongan bangsawan, orang kaya atau golongan satu agama) namun sejatinya untuk seluruh bangsa Indonesia (Djoko Dwianto, 2012, 86). Padahal jika kita memiliki esensi keinginan untuk tidak saling menjauh dari segenap jiwa manusia Indonesia tidak menutup kemungkinan jika bangsa ini menjadi bangsa yang besar yaitu bangsa yang mampu bangkit dalam menyelesaikan segala persoalan di seluruh bidang kehidupan bermasyarakat, berbangsa dan bernegara.

Nilai persatuan sebagai sebuah konsep ketrampilan dalam konteks Indonesia artinya dari pemahaman nilai substansialnya sebagai pandangan hidup bangsa, yaitu nilai persatuan sebagai sebuah konsep yang mengandung kebaikan yang luhur harus diterapkan oleh generasi baru bangsa ini. Nilai persatuan bukanlah sebagai sebuah cerita rakyat yang terbatas sebagai sesuatu yang utopis. Nilai persatuan bukanlah sebagai suatu hal yang berkutat pada retorika belaka. Namun nilai persatuan merupakan suatu nilai yang memiliki tafsir nyata dalam sejarah perjuangan bangsa Indonesia. Namun saat ini nilai persatuan hanya sebatas dilafalkan oleh bangsa yang mulai lupa akan kedahsyatan dari hakikat sila persatuan ini. Budaya baru (sebut globalisasi) yang merasuki negeri ini telah menjadi sebuah tantangan nyata dan baru akan eksistensi persatuan bangsa Indonesia. Mulai beberapa daerah yang ingin melepaskan diri dari negara Indonesia telah menjadi tanda bahwa bangsa ini sudah tidak mampu lagi untuk menempatkan nilai persatuan sebagai sebuah konsep pemahaman bagi bangsa Indonesia, apalagi jika ditempatkan sebagai konsep ketrampilan dalam memecahkan segala persoalan yang dihadapinya.

Secara kontekstual positif seharusnya nilainilai yang tercermin pada Sila Persatuan Indonesia dapat teraplikasi secara utuh dalam kehidupan manusia Indonesia baik bermasyarakat, berbangsa dan bernegara. Realita di lapangan menunjukkan konsep - konsep terkait nilai-nilai yang terkandung dalam Sila ketiga ini masih belum dapat dipahami secara utuh yang sejatinya harus menjadi jati diri bangsa Indonesia itu sendiri. Munculnya kembali gerakan-gerakan politik yang ingin mengubah Ideologi dasar Negara Indonesia yaitu Pancasila untuk dipersandingkan, diuji keabsahannya bahkan samapai pada taraf penggantian norma dasar tersebut merupakan kenyataan pahit yang harus dihadapi oleh bangsa ini. Gerakan-gerakan seperti ini justru akan mengakibatkan terjadinya disintegrasi bangsa.

Perkembangan politik yang seharusnya sinergi dengan nilai-nilai persatuan justru menjadi antipati terhadap kesakralan akan nilai-nilai luhur tersebut. Politisi yang baik akan selalu mengawal akan tegaknya nilai-nilai luhur persatuan untuk kemajuan Negara Republik Indonesia. Namun hari ini apa yang kita lihat, apa yang kita rasakan melalui media-media sosial banyak dari politisi di negeri ini yang mengeyahkan nilai-nilai tersebut. Banyak terjadi saling hina, saling memaki, bahkan saling melempar kursi pada saat digelarnya rapat merupakan contoh realistis yang mencerminkan memudarnya rasa persatuan pada dunia perpolitikan di negeri ini. Patut kita pahami bahwa sistem politik yang baik adalah sistem politik yang dipimpin oleh sebuah sistem yang mengandung nilai-nilai etika politik, kenyataan di Indonesia hari ini dan hari-hari sebelumnya (sebut :fase perjuangan kemerdekaan) bukan Sistem yang menyetir manusia melainkan manusia yang menyetir sistem. Hal ini kemudian menjadikan sebuah sistem menjadi tidak sehat dan untuk menyehatkannya kembali harus memulai dari pengetahuan dan pemahaman kembali aka kesakralan nilai-nilai beretika luhur tersebut pernah menjadi senjata ampuh yang mampu mengantarkan bangsa ini ke depan pintu kemerdekaan, bahkan sampai merdeka.

Kondisi Perekonomian di negeri ini dapat dikatakan juga masih belum stabil menuju harapan akan terwujudnya persatuan perekonomian Indonesia yang utuh. Hal ini tercermin dari naikturunnya harga barang kebutuhan pokok, harga bahan bakar yang semakin mahal, melemahnya nilai rupiah terhadap nilai dolar, jurang pemisah antara si kaya dan si miskin dalam perbandingan antara pemenuhan kebutuhan hidup melawan gaya hidup. Seandainya saja keuangan negara di tempat kelahiran kita ini benar-benar digunakan untuk 
pembangunan manusia Indonesia secara utuh kemungkinan besar realita sosial yang sering kita jumpai di lapangan tidak akan terjadi peningkatan seperti kaum fakir miskin di kampung-kampung, gelandangan dan pengemis sejati artinya bukan mereka yang menjelma menjadi gelandangan dan pengemis jadi-jadian (sebut : yang menjadikannya sebagai mata pencaharian), banyak orang tua yang masih sibuk untuk memenuhi kebutuhan sekolah putra-putri-nya meskipun SPP mereka sudah digratiskan oleh pemerintah sampai jenjang sekolah jenjang menengah atas, masih banyaknya saudara-saudara kita dimana hidupnya terlilit hutang, sehingga untuk mengetuk hati manusia Indonesia secara umum muncul program TV swasta yang berjudul "Microfon Pelunas Hutang", dan lain sebagainya.

Dari segi budaya, banyak kalangan generasi pemuda Indonesia (sebut saja generasi z) yang lebih peka mengenal budaya modern dari pada budaya tradisional bangsa Indonesia. Alasan "kuno" sering muncul pada statemen mereka sebagaimana dapat kita lihat dalam komentar di media-media sosial. Hal ini tentu menjadikan nilainilai persatuan dalam bidang budaya yang berakar pada budaya luhur bangsa kurang tertanam dalam benak pemuda Indonesia. Masa kini.

Media sosial yang kini sangat tenar sebagaimana masuk dalam kebutuhan pokok manusia Indonesia yang tanpa melihat jenjang usia juga menjadi media yang dilematis antara nilai fungsi positif dan negatif.Menurut Sularsih Condro Rini dalam kumpulan abstrak Kongres Pancasila IX Pancasila Jiwa Bangsa $(2017 ; 17)$ menerangkan bahwa sering kali ditemukan berita-berita yang diragukan kebenaran dan validitasnya namun ditelan secara mentah-mentah oleh beberapa pihak sebagai berita valid yang dikemudia hari memunculkan kotak-kotak perbedaan.betapa berpengaruhnya media social dalam penyebaran berita, terlebih lagi bagi orang-orang yang enggan untuk menelaah lebih jauh kebenaran tersebut. Keyakinan yang telah mengakar, titik kesukaran dalam menerima perbedaan keyakinan atau pemahaman kemudian memunculkan pihak-pihak radikal.

Indonesia adalah Negara yang ber-bhinneka tunggal ika, dengan Pancasila sebagai ideology, tidak seharusnya perbedaan justru dijadikan sebagai alasan akan terjadinya pertikaian antar saudara setanah air. Ketika media sosial dijadikan sebagai media penyebaran berita hoax, maka alahkah baiknya jika media sosial digunakan sebagai media pemersatu bangsa dengan menyebarkan nilai-nilai terkait Persatuan Indonesia. Sebagai warga Negara yang baik sudah selayaknya kita turut menjaga kerukunan antar saudara setanah air.

Dari segi Pertahanan dan Keamanan Negara, menurut Lilya Windi Pramesti dalam kumpulan abstrak Kongres Pancasila IX Pancasila Jiwa Bangsa $(2017$; 17), terorisme merupakan fenomena sosial yang selalu dihubungkan dengan radikalisme yang muara akhirnya dapat mempengaruhi bahkan mengancam persatuan Indonesia, khususnya dalam bidang pertahanan keamanan. Radikalisme bersumber pada pemahaman yang literal, parsial dan menganggap ajarannya yang paling benar tanpa diukur dari perspektif nilai-nilai yang mampu mewujudkan persatuan Indonesia. Media sosial telah tergerak menuju pembuadayaan nilai yang anti dalam penegakan nilai persatuan, dimana digunakan oleh segelintir kelompok yang tidak bertanggung jawa terhadap eksistensi negeri ini. Media sosial sebagai media yang paling efektif menjadi sumber komunikasi kelompok radikal untuk memperluas jaringannya, menyebarkan doktrin, merekrut keanggotaan, propaganda melalui berbagai tulisan, gambar atau video yang bersifat provokatif, bahkan aksi ancaman yang dapat mengganggu sistem pertahanan dan keamanan nasional.

Beberapa daerah di Indonesia yang sering mengalami konflik internal dan ekternal dapat menambah khasanah permasalahan negeri ini di bidang pertahanan dan keamanan negara. Sebut saja saudara-saudara kita yang berada di timur, yang beberapa kali ingin melepaskan diri dari Indonesia, tentu hal ini menjadi keadaan yang berada pada tingkat sangat mencemaskan. Belum lagi konflik yang mengatasnamakan agama serta golongan-golongan tertentu (sebut saja Poso) justru menambah carut-marut stabilitas keamanan negara Indonesia. Menurut Agustanty E.S, dkk dalam bukunya yang berjudul "Revitalisasi Kearifan Lokal" (Studi Resolusi Konflik di Kalimantan Barat, Maluku dan Poso), sejarah tragedi kemanusiaan yang terjadi di Poso ditandai dengan tindak kekerasan dengan menggunakan berbagai jenis senjata, baik rakitan maupun organik. Juga digunakan bom dan senjata tajam. Awal peristiwa konflik Poso adalah terjadinya pemuda di kelurahan Sayo antara Roy Bisalemba dan Tely 
Langingi (Kristen) versus pemuda (muslim) yang kemudian tersebar isu bahwa "ada seorang muslim yang dipotong-potong di dalam mesjid Sayo". Akhirnya berkembanglah konflik terbuka yang semakin sulit untuk dihindari. Saling serang antar kelompok Islam dengan kelompok Kristen. Jika kita lihat sampai hari ini konflik semacam ini juga sering kambuh atau sedang mati suri kemudian terjadi lagi di kemudian hari. Maka dari itu tentu kita sebagai warga negara yang baik, warga negara yang mampu menjunjung tinggi nilai-nilai persatuan harus mampu menjadi pembawa obor, memberikan penguatan suri tauladan yang baik dengan tujuan menyebarkan nilai-nilai persatuan Indonesia sesuai dengan kapasitas kita masingmasing.

Penjelasan lain secara kontekstual positif (sebut : secara umum) implementasi nilai-nilai Persatuan Indonesia (sila ketiga Pancasila) juga dapat ditempuh melalui beberapa muatan perilaku sebagaimana berikut:

1. Menempatkan persatuan, kesatuan, kepentingan serta keselamatan bangsa dan negara atas kepentingan pribadi atau golongan. muatan ini menghendaki warga negara Indonesia menempatkan kepentingan negara di atas kepentingan pribadi dan golongan. Oleh sebab itu, perang antar suku, dan agama tidak perlu lagi terjadi, kita harus saling menghormati dan bersatu demi Indonesia. Pemain politik dan ekonomi tidak boleh mengorbankan kepentingan negara demi kelompoknya seperti penjualan aset negara dan masyarakat dirugikan. Oleh sebab itu, setiap warga negara harus melakukan pengawasan yang bersifat aktif terhadap penyelamatan kepentingan negara.

2. Rela berkorban demi kepentingan bangsa dan negara. Muatan ini menghendaki setiap warga negara rela memberikan sesuatu sebagai wujud kesetiaan kepada negara. Pengorbanan kepada negara ini dapat dilakukan dengan menjadi militer sukarela, menjaga keamanan lingkungan, menegakkan disiplin, dan sebagian besar warga negara dilakukan dengan bekerja keras dan taat membayar pajak sebagai kewajiban warga negara.

3. Cinta tanah air dan bangsa. Muatan ini menghendaki setiap warga negara mencintai atau adanya keinginan setiap warga negara memiliki rasa ke-Indonesiaan. Kecintaan akan Indonesia dapat dilakukan dengan mengagungkan nama Indonesia dalam berbagai kegiatan seperti Olimpiade olahraga maupun Ilmu Pengetahuan, meningkatkan kemampuan sumber daya manusia, dan melestarikan kekayaan alam dan budaya Indonesia.

4. Bangga sebagai bangsa Indonesia bertanah air Indonesia. Muatan ini menghendaki adanya suatu sikap yang terwujud dan tampak dari setiap warga negara Indonesia untuk menghargai tanah air Indonesia, mewarisi budaya bangsa, hasil karya, dan hal-hal yang menjadi milik bangsa Indonesia. Sikap bangga ini ditunjukan dengan berani dan percaya diri menunjukan identitas sebagai warga negara Indonesia baik lewat budaya, perilaku, dan teknologi yang berkembang di Indonesia, mencintai produk Indonesia adalah wujud rasa bangga bertanah air Indonesia

5. Memajukan pergaulan demi persatuan dan kesatuan bangsa yang ber-Bhineka Tunggal Ika. Muatan ini menghendaki adanya pergaulan, dan hubungan baik ekonomi, politik, dan budaya antar suku, pulau dan agama, sehingga terjalin masyarakat yang rukun, damai, dan makmur. Kemakmuran terjadi karena pada dasarnya setiap suku, agama, dan pulau mempunyai kekhususan yang bernilai tinggi, dan hal ini juga bermanfaat bagi yang lain, sehingga tukar-menukar ini akan meningkatkan nilai kesejahteraan bagi manusia.

Pancasila yang memiliki sumber pengetahuan dan nilai-nilai luhur sudah seharusnya dapat diimplementasikan oleh setiap masyarakat Indonesia. Pancasila tidak sekedar menjadi sebuah simbol akan tetapi sejatinya memiliki arti dan sumbangsih dalam menyelesaikan persoalan bangsa dan negara secara bersama-sama (Kirom, 2011: 101).

\section{SIMPULAN}

1. Pada hakekatnya sifat dan keadaan bangsa dan negara Indonesia adalah "satu" yaitu dapat diartikan mutlak dan tidak dapat terbagi oleh apapun. Meskipun keberagaman yang didalamnya banyak terdapat unsur perbedaan bukanlah menjadi penghalang bangsa Indonesia untuk terus memperkuat rasa yang satu yaitu semangat persatuan Indonesia (nasionalisme).

2. Persatuan Indonesia adalah persatuan yang berke-Tuhanan YME, yang berkemanusiaan 
yang adil dan beradab, yang berkerakyatan yang dipimpin oleh hikmat kebijaksanaan dalam permusyawaratan /perwakilan serta yang berkeadilan sosial bagi seluruh rakyat Indonesia.

\section{DAFTAR RUJUKAN}

Dwiyanto, Djoko. 2012. Pendidikan Karakter Berbasis Pancasila. Yogyakarta: Ampera Utama

Kaelan. 2009. Filsafat Pancasila "Pandangan Hidup Bangsa Indonesia". Yogyakarta: Paradigma.

Kirom, Syahrul. 2011. Filsafat Ilmu dan Arah Pengembangan Pancasila: Relevansinya Dalam Mengatasi Persoalan Kebangsaan. Jurnal Filsafat UGM, Vol 21, No. 2
3. Dengan demikian pertalian dan hidup kebangsaan kita bukan merupakan tujuan rakyat Indonesia, akan tetapi tidak lain adalah sebagai alat atau cara kita untuk mencapai hidup bersamayang berpersatuan Indonesia.

Kumpulan Abstrak Kongres Pancasila IX Pancasila Jiwa Bangsa " Dinamika, Tantangan, dan Aktualisasi di Indonesia. 2017. Yogyakarta: Gadjah Mada University Press.

Tamagola, Tamrin Amal, dkk. 2006. Revitalisasi Kearifan Lokal (Studi Resolusi Konflik di Kalimantan Barat, Maluku dan Poso). Jakarta: ICIP. 